\title{
Nasionalisme dan kelas sosial: Ideologi dan praktik partai nasionalis di Indonesia
}

\section{Nationalism and social class: Nationalism parties ideology and practice in Indonesia}

\author{
Retor Kaligis \\ Ilmu Kesejahteraan Sosial \\ Sekolah Tinggi Ilmu Sosial dan Ilmu Politik (STISIP) Widuri, Jakarta, Indonesia \\ Jalan Palmerah Barat 353, Jakarta Selatan, Indonesia \\ E-mail: retor_awk@yahoo.com
}

\begin{abstract}
This study explores poor people or negative ownership class phenomena as result of exploitative ideology by using power including exploitation of natural resource and placement of population as cheap labor. This study explores poor people or negative ownership class phenomena as result of exploitative ideology by using power, including exploitation of natural resource and placement of human resources as cheaper labor. Although many studies about Indonesian nationalism were conducted previously, but generally the study of nationalism in relation to the poor people class in Indonesia are not the main focus of the study.This article using qualitative research method. In order to compare different phenomena in various periods, this article uses historical comparative research method. There were five levels in historical comparative research. First, is conceptualizing the object of inquiry. Second is locating the evidence. Third is evaluating quality of evidence. Fourth is organizing evidence. Fifth is syntesizing. An open interviewed was conducted with stakeholders whose directly involved in many cases within several political party bodies such as Partai Nasional Indonesia (PNI), Partai Demokrasi Indonesia (PDI). Data was analyzed by social, cultural, and political interpretation. It can be concluded tht in national politic constellation, the phenomena of poor class produce a defense term for their group, known as 'marhaen' and 'wong cilik'. Nevertheless, nationalism practice in Indonesia as represented by PNI, PDI, dan PDI Perjuangan, have not yet succedeed to freed poor people from social aleniation in political power contestation, the ownership of capital, or in relations between state and government. This nation still struggled to build competitive political and economical power in order to reate a social transformation.
\end{abstract}

Keywords: nationalism, political party, negative ownership class

\begin{abstract}
Abstrak
Penelitian ini adalah studi tentang fenomena rakyat kecil atau kelas kepemilikan negatif sebagai akibat ideologi eksploitatif melalui penggunaan kekuasaan, menyangkut eksploitasi sumber daya alam dan penempatan penduduknya sebagai sumber tenaga murah.Walaupun banyak kajian tentang nasionalisme Indonesia ditulis, akan tetapi umumnya pembahasan nasionalisme dalam hubungannya dengan rakyat kecil di Indonesia tidak menjadi pusat kajian. Penelitian ini menggunakan metode kualitatif. Untuk memperbandingkan fenomena pada masa yang berbeda digunakan historical-comparative research. Terdapat lima tahap dalam penelitian perbandingan sejarah. Pertama, mengonseptualisasi obyek penyelidikan (conceptualizing the object of inquiry). Kedua, menemukan bukti (locating evidence). Ketiga, mengevaluasi kualitas bukti (evaluating quality of evidence). Keempat, mengorganisir bukti (organizing evidence). Kelima, melakukan sintesis (syntesizing). Dilakukan wawancara terbuka dengan sejumlah kalangan yang kompeten/terlibat langsung dalam berbagai peristiwa di PNI, PDI, dan PDI Perjuangan. Analisis data dilakukan dengan cara melakukan interpretasi sosial, kultural, dan politik. Dapat disimpulkan bahwa dalam politik nasional, fenomena rakyat kecil dan kemiskinannya melahirkan istilah khasnya sebagai pembelaan terhadap mereka, yakni marhaen dan wong cilik. Meski begitu, praktik nasionalisme di Indonesia, sebagaimana direpresentasikan oleh PNI, PDI, dan PDI Perjuangan, belum berhasil membebaskan rakyat kecil dari penutupan sosial dengan pengucilan dalam medan konflik dan kompromi antar kekuatan politik lain, kekuatan modal, maupun relasi dengan negara dan pemerintah.Bangsa ini mengalami kesulitan membangun politik-ekonomi yang berdaya saing untuk melakukan transformasi sosial.
\end{abstract}

Kata Kunci: nasionalisme, partai politik, kepemilikan kelas negatif 


\section{Pendahuluan}

Di Indonesia pada Era Orde Baru, pembahasan kelas sosial seolah tabu karena diasosiasikan dengan Komunisme. Di dunia akademis sendiri, kajian kelas sosial sempat mengalami stagnasi pada era 1980-an. Baru pada 1999 Harriet Bradley dan Gail Hebson dalam International Journal of Sociology and Social Policy mengajak mereartikulasi kelas sosial dan membawanya ke tengah perdebatan ilmu sosial, khususnya sosiologi, dan setahun kemudian Aage Sorensen dari Universitas Harvard dalam American Journal of Sociology mengupas eksploitasi berbasiskan rente (Jalal 2003: 135-9). Kajian kelas sosial lalu bermunculan dari sejumlah ilmuwan, baik (Neo) Marxis dan (Neo) Weberian, penganut aliran Max Weber.

Meski dapat dilihat dari berbagai sudut pandang, inti pembahasan kelas sosial bermuara pada persoalan relasi antar kelompok status sosial-ekonomi di masyarakat yang tak jarang ada kelompok masyarakat mengalami marjinalisasi dan eksploitasi oleh kelompok masyarakat lain. Relevannya suatu kategori kelas sosial terletak pada basis realitas empiris dalam menjelaskan kondisi sosio-historis masyarakat tertentu. Perkembangan kapitalisme industri di Eropa abad ke 19 melahirkan kelas proletar yang tidak memiliki alat produksi sendiri dan berhadapan dengan kelas borjuasi. Karl Marx dan Friedrich Engels dengan Das Kapital-nya mengasumsikan, strukturstruktur kekuasaan politis dan ideologis ditentukan struktur kekuasaan di bidang ekonomi.

Namun di Nusantara sejak masa kolonial, faktor ideologi eksploitatif justru berperan mengubah struktur kekuasaan di bidang ekonomi. Proses pembentukan kelompok sosial bawah banyak ditentukan faktor operasi ideologi yang mengeksploitasi sumber daya alam dan penempatan penduduk sebagai buruh murah. Kolonialisme dan imperialisme merombak struktur kekuasaan di bidang ekonomi dengan merusak jalur perdagangan, pelayaran, penguasaan tanah, hingga pertukangan. Antonio Gramsci menyoroti bahwa ideologi bukan hanya sekadar refleksi dari realitas material, karena ideologi merupakan konsepsi kehidupan yang tampak pada segala aspek eksistensi individual dan kolektif. Ideologi "menggerakkan" massa manusia, dan menciptakan ruang bagi manusia untuk bergerak, memperoleh kesadaran atas posisi dan perjuangan mereka, dan sebagainya (Gramsci 1995: 327).

Ada anggapan negeri eks kolonial Belanda memiliki hambatan untuk maju di era merdeka. Para ahli pascakolonial sendiri menganalisis tentang karakteristik kolonialisme yang memengaruhi aspek-aspek politik, ekonomi, sosial, dan kultural di masyarakat bekas jajahan.Ania Loomba menyimpulkan, "Colonialism' is not just something that happens with the collusion of forces inside, but a version of it can be duplicated from within" (Loomba 2005: 16). Soekarno berpendapat, perbedaan basis material penjajah memengaruhi cara kolonialisme. Dengan terpaan Revolusi Industri, industri di Inggris berkembang hingga mengalami overproduksi. Inggris menjajah untuk memperluas pasar sehingga sejak awal sistem kolonialismenya di India membuka sekolah dan universitas guna mendorong kemauan dan daya beli masyarakatnya. Berbeda dengan Inggris, Belanda menjajah untuk mencari bahan mentah. Pendidikan diselenggarakan terbatas dan diperuntukkan bagi strata tertentu. Kekayaan alam negeri ini dieksploitasi, rakyatnya dijadikan buruh murah setelah penguasaan tanah kolonialisme merampas sumber penghidupannya (Soekarno 1984: 5-19).

Di masa pascakolonial, negeri ini terus jadi penjaja sumber daya alam dan sumber tenaga murah. Kekayaan alam lebih banyak dinikmati segelintir pemodal dalam dan luar negeri. Kebijakan eksploitatif di sektor perkebunan, pertambangan, industri, dan kehutanan terus memarjinalkan penguasaan tanah rakyat. Rakyat tak dipupuk oleh cita-cita mengelola sumber daya alamnya secara mandiri. Sejak Orde Baru pembukaan besar-besaran perkebunan, pertambangan, industri, dan kehutanan menjadi sumber utama sengketa lahan yang menyebabkan distribusi penguasaan tanah semakin timpang.Konsorsium Pembaruan Agraria (KPA) mencatat terdapat sekurangnya 10,89 juta hektar sengketa lahan dan mengorbankan 1,19 kepala keluarga di 286 Kabupaten/ Kota sejak tahun 1970 hingga 2001 (Tjondronegoro dan Wiradi [ed] 2008:407). 
Mayoritas kaum tani hanya memiliki tanah kurang dari 0,5 ha atau bahkan tidak bertanah (buruh tani) dengan peralatan produksi sederhana dan infrastruktur minim. Berdasarkan Sensus Pertanian terakhir (2003), terdapat14,02 juta $(56,41 \%)$ rumah tangga pertanian menguasai lahan kurang dari 0,5 hektar (BadanPusat Statistik 2005a:42). Dari segi pekerjaan, terdapat 34,99 juta $(60,34 \%)$ petani dan 14,37 juta $(24,77 \%)$ buruh tani (Badan Pusat Statistik 2005b: lampiran 3). Dengan demikian, mayoritas kaum tani merupakan petani kecil (gurem).

Selain itu, sebagian besar nelayan masih merupakan buruh yang bekerja pada pemilik perahu. Nelayan buruh merupakan kelompok masyarakat miskin yang dominan di desa-desa nelayan. Faktor kemiskinan membuat mereka hidup dan terpintal ke dalam jaringan utang-piutang yang intensif (Kusnadi 2003:33-4). Ada pula perajin dengan industri rumah tangganya, pedagang kecil di kaki lima dan pasar tradisional. Mereka tidak dapat dikategorikan kelas proletar. Dalam terminologi Marxisme, mereka disebut transitional class- sebuah kelas yang akan punah. Padahal di Indonesia, mereka tidak terlihat tanda-tanda kepunahan melainkan kian terdesak sektor modern. Menurut data BPS September 2006, 63,41\% mayoritas penduduk miskin berada di desa (Khudori 2007). Terpisahnya rakyat desa dari sumber kehidupannya mendorong proletarisasi masif. Dengan angkatan kerja berpendidikan rendah, arus urbanisasi kian menambah kaum miskin perkotaan. Sejak Orde Baru, sebagian besar penanaman modal asing (PMA) di Indonesia bersifat footloose industry, yakni jenis industri yang didirikan dengan hanya mempertimbangkan biaya produksi murah di lokasi baru, dan lokasi pabriknya mudah dipindah ke negara lain tanpa menanggung kerugian berarti atas investasi yang sudah ditanam, seperti tekstil, sepatu, dan elektronika (Widarjono 2002). Dengan karakter tersebut, tuntutan perbaikan kesejahteraan dipandang melemahkan iklim investasi di sektor industri.

Untuk memperbaiki nasib, banyak orang mengadu nasib menjadi tenaga kerja ke luar negeri karena faktor penarik dan faktor pendorong. Upah yang lebih tinggi di luar negeri menjadi faktor penariik. Adapun faktor pendorong adalah situasi pasar tenaga kerja domestik yang kelebihan suplai, situasi ketenagakerjaan di Indonesia yang masih ditandai dengan tingginya tingkat pengangguran terbuka dan masih lambatnya daya serap tenaga kerja di lapangan kerja formal. Lapangan kerja di sektor informal sendiri umumnya dicirikan dengan produktivitas dan pendapatan yang rendah (Supriana dan Nasution 2010: 43). Padahal, mayoritas dari sekitar 7 juta warga Indonesia yang bekerja di luar negeri menjadi buruh kasar dan pekerja rumah tangga tanpa kemampuan memadai (unskilled) (Kaligis 2010).

Frank Parkin, salah seorang Weberian, mendefinisikan hubungan antar kelas bukan berkaitan dengan tempatnya dalam proses produksi melainkan dalam konteks penggunaan kekuasaan yang melakukan cara penutupan sosial dengan pengucilan (social closure as exclusion) sebagai cara utama pembentukan kelas. Dalam masyarakat kapitalis modern, ada dua cara pengucilan utama yang digunakan borjuasi untuk membentuk dan mempertahankan dirinya sebagai suatu kelas. Pertama, berkaitan lembaga pemilikan dan, kedua, berkaitan keahlian akademis atau profesional. Masing-masing mencerminkan seperangkat pengaturan legal yang membatasi jalan untuk mendapatkan ganjaran dan hak istimewa. Pemilikan adalah bentuk penutupan untuk membatasi jalan terhadap alat-alat produksi dan hasilnya. Persyaratan keahlian atau profesionalisme adalah bentuk penutupan yang dimaksud untuk mengontrol dan memantau penerimaan ke dalam posisi kunci dalam pembagian kerja. Kedua jenis penerima keuntungan praktik pengucilan yang dipaksakan negara ini, dapat dianggap sebagai komponen-komponen utama dari kelas dominan di bawah sistem kapitalisme modern. Kelas yang kepemilikannya serba terbatas (dibatasi) disebut Parkin kelas kepemilikan yang negatif (Parkin 1979: 44-73).

Konsep Frank Parkin tentang pembentukan kelas sosialmendekati realita fenomena marjinalisasi dan eksploitasi di Indonesia, yang melahirkan istilah marhaen dan kemudian populer pengertian wong cilik sebagai entitas politik. Istilah marhaen, menurut Soekarno, diambil dari nama seorang petani yang ditemui di sebelah selatan kota Bandung pada tahun 1920-an. Si petani itu memiliki aset produksi, yakni sebidang tanah kecil dan cangkul (Adams 1966:82-5). Ketika pertama kali mengemukakan istilah itu secara tertulis pada pidato pembelaannya berjudul "Indonesia 
Menggugat" di Pengadilan Kolonial di Bandung tahun 1930, Soekarno menyebut marhaen adalah(Soekarno dalam Soenario 1988: 311-2). Semua golongan kromo (kecil), baik petani kecil, buruh kecil, pedagang kecil, nelayan kecil, dan sebagainya. Mereka dimelaratkan oleh imperialisme, kolonialisme, dan kapitalisme yang telah mematikan perdagangan, pelayaran, dan petukangan di nusantara bagi kepentingan penjajah.

Untuk membebaskan kaum marhaen dari marjinalisasi dan eksploitasi, Soekarno menelurkan marhaenisme, yakni sosio-nasionalisme (gabungan konsep nasionalisme dan perikemanusiaan) untuk mendorong sosio-demokrasi (demokrasi dan keadilan sosial) (Soekarno 1984). Berbeda dengan pengertian Karl Marx tentang kelas sosial proletar, bagi Soekarno, marhaen adalah semua kalangan yang dimarjinalkan secara ekonomi- baik memiliki aset produksi maupun tidak. Jika merujuk pada konsep Parkin, marhaen merupakan kelas kepemilikan yang negatif akibat penggunaan kekuasaan, dimana kaum tani terdesak dari sumber kehidupannya, kemampuan nelayan dengan kemampuan serba minim terus berkubang dalam kemiskinan, pedagang kecil terpinggirkan di sektor perdagangan, hingga lemahnya posisi tawar buruh dalam industrialisasi. Kelas kepemilikan negatif juga tidak memiliki syarat akademis atau profesional menjadi kelas menengah. Di era kemerdekaan, marhaen dan marhaenisme menjadi simbol identitas perjuangan PNI (Partai Nasional Indonesia). Adapun wong cilik adalah istilah Jawa yang asal-usulnya berasal aristocratic relations. Akan tetapi, Clifford Geertz yang melakukan penelusuran sejarah sosial kota di Mojokuto, Jawa Timur dari saat didirikannya sekitar pertengahan abad ke-19 hingga pertengahan abad ke-20- saat ia melakukan penelitian antropologis tahun 1952-1954- menemukan istilah itu digunakan untuk menunjuk rakyat kecil di sana. Rakyat kecil di Mojokuto mengalami imbas dari Perang Jawa (1830), sistem tanam paksa (1830-1870), pembangunan industri pertanian dan perkebunan oleh kolonial, termasuk pertentangannya dengan perusahaan penggilingan tebu, hingga kegagalan negara baru (Indonesia) untuk menangani secara tepat masalah-masalah ekonomi, politik, dan sosial yang berdampak pada kota ini beserta lingkungan pedesaannya. Mereka terdiri dari kaum petani melarat -memiliki sepetak tanah maupun tidak, buruh perusahaan tebu,para pedagang kecil di sekitar mesjid dan pasar, dan kaum miskin lainnya (Geertz 1986: 16).Dengan demikian, setelah muncul melalui aristocratic relations, marjinalisasi ekonomi wong cilik diakibatkan oleh eksploitasi kolonialisme dan kapitalisme.

Istilah wong cilik pertama kali digunakan menjadi kosa kata politik nasional pada akhir 1980-an ketika Ketua Umum DPP PDI Soerjadi mempopulerkannya sebagai wacana pembelaan partai ini terhadap rakyat kecil.Di tengah desoekarnoisasi oleh Orde Baru, tidak digunakannya istilah marhaen tak terlepas dari kekhawatiran pimpinan partai ini dikaitkan dengan Orde Lama. PDI, berlanjut pada PDI Perjuangan, mentranformasi istilah marhaen menjadi wong cilik untuk identitas keberpihakan bagi rakyat kecil yang dianggap cocok dengan perkembangan politik. Istilah wong cilikyang menjadi populer melampau etnis Jawa dan menasional di tengah menguatnya konglomerasi dan dimulai era liberalisasi ekonomi di Indonesia setelah diterbitkannya serangkaian paket kebijakan ekonomi pada dekade 1980-an. Istilah wong cilik lalu memperoleh sentimen di masyarakat yang merasakan adanya kesenjangan sosial. Artinya, dalam konteks politik nasional sejak satu dekade terakhir Orde Baru, pengertian wong cilik memiliki pemaknaan yang sama dengan marhaen, yakni kelas kepemilikan negatif yang mengalami penutupan sosial dengan caracara pengucilan berkaitan penggunaan kekuasaan. Ia mengalami operasi ideologi kelas dominan yang mengeksploitasi sumber daya ekonomi dan penempatan penduduk sebagai sumber tenaga kerja murah, sehingga terjadi marjinalisasi ekonomi.

Tidak semua kelas atas dan menengah melakukan dan mendukung marjinalisasi dan eksploitasi, yakni mereka yang tidak terlibat dalam proses pengucilan yang memiskinkan warga masyarakat. Para pemodal dari industri kreatif tentu berbeda relasinya dengan karyawan ketimbang pemodal industri manufaktur yang menghitung secara rinci kaitan satuan jam kerja dan upah buruh dengan hasil produksinya. Sebaliknya, di antara sesama kelas kepemilikan negatif dapat pula terlibat pengucilan, seperti aparat Tramtib yang menggusur paksa pedagang kaki lima tanpa memberikan solusi, orang suruhan dari para tengkulak untuk menekan kaum tani agar menjual panennya dengan harga murah, dan sebagainya. Kelas kepemilikan negatif dapat sadar terhadap kepentingan 
bersamanya yang mengalami pengucilan, serta memperjuangkannya melalui tindakan ekonomi atau politik yang terorganisir. Para petani dapat disatukan oleh paguyuban atau koperasi tani, demikian halnya para pedagang kaki lima, nelayan kecil, dan para buruh memiliki organisasinya sendiri. Tapi pembentukan suatu organisasi yang mewadahi seluruh anggota kelas kepemilikan negatif yang berbeda jenis pekerjaannya tersebut kurang ditemukan relevansinya karena terdapat perbedaan kepentingan menyangkut sumber penghidupan.

Dalam kehidupan modern, hubungan antar kelas sosial memerlukan penyalurannya melalui organisasi. Dari semua organisasi, menurut Weber, partai politik adalah tipe organisasi di mana perjuangan memperoleh atau menggunakan kekuasaan dinyatakan paling jelas di tingkat organisasi rasional (societal) (Paul Johnson 1986:224-5). Partai politik diharapkan dapat memperjuangkan kepentingan seluruh anggota kelas kepemilikan negatif, yang tidak dapat membentuk sendiri satu organisasi kelas dari berbagai profesi tersebut.Partai berdasarkan nasionalisme dipandang penting dari segi perjuangannya yang menganggap semua warga negar sederajat, sehingga -idealnya- tidak ada kalangan yang lebih diistimewakan dan sebagian lainnya mengalami eksploitasi. Sejak masa kolonial, gerakan nasionalisme di Indonesia melekat dengan pembelaan terhadap rakyat kecil. Akan tetapi, kajian ideoologi dan praktik nasionalisme dalam hubungannya dengan rakyat kecil di Indonesia umumnya tidak menjadi pusat kajian. Karena itu menarik untuk melihat dan memperbandingkan dinamikanya sebagaimana direpresentasikan oleh PNI, PDI, dan PDI Perjuangan di era kemerdekaan (1945-2005).

\section{Metode Penelitian}

Penelitian ini mengkaji dinamika kekuasaan dan kepentingan rakyat kecil di Indonesia sebagai negeri pascakolonial (1945-2005). Dalam kurun waktu 60 tahun kemerdekaan Indonesia, rezim penguasa memimpin silih berganti dan terdapat tiga partai politik nasionalis (PNI, PDI, PDI Perjuangan) pada periode berbeda yang menyatakan keberpihakannya pada rakyat kecil. Nasionalisme dikaitkan dengan isu keadilan sosial. Akan tetapi, selama kurun waktu tersebut, negeri yang memiliki tanah dan air luas serta kekayaan alam melimpah ini masih terus mengalami persoalan kemiskinan. Dengan demikian, penelitian diharapkan dapat mengkaji sejauhmana perjuangan nasionalisme bagi rakyat kecil, persamaan maupun perbedaannya, dalam medan konflik dan kompromi antar kekuatan politik lain, kekuatan modal, maupun relasi dengan negara dan pemerintah. Penelitian ini menggunakan metode kualitatif. Somantri (2005: 64) menjelaskan:

Penelitian kualitatif berusaha untuk mengangkat secara ideografis berbagai fonemena dan realitas sosial. Pembangunan dan pengembangan teori sosial khususnya sosiologi dapat dibentuk dari empiri melalui berbagai fenomena atau kasus yang diteliti. Dengan demikian teori yang dihasilkan mendapatkan pijakan yang kuat pada realitas, bersifat kontekstual dan historis.

Untuk memperbandingkan fenomena pada masa yang berbeda digunakan historical-comparative research.Terdapat lima tahap dalam penelitian perbandingan sejarah. Pertama, mengonseptualisasi obyek penyelidikan (conceptualizing the object of inquiry). Kedua, menemukan bukti (locating evidence). Ketiga, mengevaluasi kualitas bukti (evaluating quality of evidence). Keempat, mengorganisir bukti (organizing evidence). Kelima, melakukan sintesis (syntesizing) (Neuman 2003).

Pengumpulan data pertama-tama dilakukan melalui telaah pustaka, berupa dokumen, artikel, jurnal, berita, buku, laporan-laporan, dan sumber tertulis lainnya sebagai teks dan fakta historis. Kemudian dilakukan wawancara terbuka dengan sejumlah kalangan yang kompeten/terlibat langsung dalam berbagai peristiwa di PNI, PDI, dan PDI Perjuangan. Analisis data dilakukan dengan cara melakukan interpretasi sosial, kultural, dan politik yaitu pengolahan dan pemahaman peneliti terhadap persoalan yang diteliti, dilihat hubungan sebab-akibat dalam konteks historis tertentu, similarity dan dissimilarity, serta kontinuitas dan diskontinuitas antara PNI, PDI, dan PDI Perjuangan.Pada tahap penyajian data, disajikan hasil analisis tentang ideologi dan praktik 
nasionalisme sebagaimana direpresentasikan oleh PNI, PDI, dan PDI Perjuangan dalam konteks politik dan kemasyarakatan yang berbeda.

\section{Hasil dan Pembahasan}

\section{Aspek sebab-akibat}

Pada fenomena kemiskinan rakyat kecil dalam dinamika konsolidasi bangsa di masyarakat majemuk Indonesia, baik PNI, PDI, maupun PDI Perjuangan menghadapi persoalan dampak ideologi eksploitatif yang memarjinalkan rakyat dari basis kehidupannya dan menjadikan penduduk sebagai sumber tenaga murah. Indonesia di masa awal kemerdekaan menghadapi kepentingan kolonialisme Belanda yang berupaya melemahkan eksistensi republik melalui jalur militer dan perundingan. Unsur-unsur dari dalam negeri, terutama kalangan feodal, berusaha mempertahankan hak-hak istimewanya yang diakui pada zaman kolonial Belanda. Dalam dinamika politik tersebut, PNI menerjemahkan persamaan kesempatan di bidang politik dan ekonomi sebagai revolusi sosial, sehingga partai ini melibatkan diri dalam revolusi sosial tahun 1946, khususnya di Jawa Tengah. Setelah pemerintah pusat tidak mendukung revolusi sosial, PNI berusaha melakukan kompromi dengan sumber-sumber kekuasaan. Akhirnya, PNI lebih mempertimbangkan kepentingan taktis politik, terutama dalam rangka meraih kedudukan di kabinet dan parlemen (Rocamora 1991:441-2).

Di era Demokrasi Liberal, pengusaha nasional mulai tumbuh. Para elite nasionalis yang mulai terjun menjadi pengusaha belum mendukung liberalisme ekonomi karena di samping wacana nasionalisme sangat kuat dalam kehidupan politik nasional, keberadaan kaum borjuasi yang baru tumbuh saat itu masih menganggap kapitalisme asing sebagai ancaman bagi kelangsungan usahanya. Namun, pembangunan ekonomi rakyat seperti kemajuan koperasi, pemberdayaan serikat buruh dan taniyang sudah menjadi komitmen PNI kalah prioritas. Usaha PNI meraih sumber-sumber kekuasaan mulai bercampur kepentingan memperoleh sumber-sumber ekonomi. Bagin (2002:222-3) menjelaskan, kantor PNI itu seperti kantor makelar, baik untuk menduduki jabatan pemerintahan, maupun untuk mendapat lisensi istimewa, termasuk mendapat jatah gula dari Persatuan Pedagang Gula Indonesia (PPGI).

Unsur antikapitalisme yang melemah diperburuk dengan semakin sulitnya PNI mengambil garis antifeodalisme ketika partai ini berhasil mencari dukungan di lingkungan birokrasi. Penyebabnya, anggota partai yang berada di lingkungan birokrasi, terutama di Departemen Dalam Negeri, justru mengambil keuntungan dari otoritas "feodal". Jaringan birokrasi itu lalu digunakan oleh PNI dalam menghadapi Pemilu 1955 yang kemudian dimenangkannya. PNI mendapatkan keuntungan yang luar biasa karena pengaruhnya yang semakin kuat pada korps pegawai negeri di pemerintahan daerah dari mana ketua panitia pemilihan biasanya diambil (Rocamora 1991:160 dan 442). Konflik ideologi dan politik yang berlarut-larut di era Demokrasi Liberal menyebabkan kerjasama-kerjasama politik yang berlangsung lebih berorientasi jangka pendek. Walaupun PKI termasuk partai empat besar, Kabinet Ali Sastroamidjodjo yang kedua tidak mengikutsertakannya dalam kabinet. PNI bekerjasama dengan partai-partai Islam, termasuk Masyumi, ditambah Parkindo, Partai Katolik, dan partai kecil lainnya untuk memperkuat kedudukannya di DPR. Namun, Jeanne S. Mintz mencatat, ketika Kabinet Ali yang kedua berjalan, PNI kembali berseberangan dengan Masyumi dan bersekutu dengan hampir semua partai lainnya dalam kabinet melawan partai itu(Mintz 2002:182).Energi partai-partai politik terkuras dalam koalisi dan konflik tanpa dibangun kerangka kerja bersama berbagai kekuatan politik untuk membebaskan rakyat kecil dari kondisi penutupan sosial dengan pengucilan.

PNI berperan menelurkan UUPA Tahun 1960 UU No. 5 Tahun 1960 Tentang Peraturan Dasar Pokok-Pokok Agraria (UUPA Tahun 1960) yang diperjuangkan ketika Menteri Agraria dijabat kadernya, Sadjarwo. UU tersebut berasal dari "Rancangan Sadjarwo" yang disetujui Kabinet-Inti dalam sidangnya tanggal 22 Juli 1960 dan Kabinet-Pleno dalam sidangnya tanggal 1 Agustus 1960. Namun PNI tidak berhasil mengawal pelaksanaan UUPA Tahun 1960 karena banyak 
aktivisnya menjadi tuan tanah, korup, dan berpihak kepada tuan tanah. Di Jawa Tengah, Jawa Timur, dan Bali di mana PNI memiliki banyak anggota dan pendukung di kalangan kelompok pemilik tanah, DPD PNI memanfaatkan pengaruhnya untuk menolong para tuan tanah mengelak dari UUPA(Rocamora 1991:411). Pada masa awal Orde Baru, sentralisme kekuasaan politik Orde Baru menghambat peran PNI dan partai-partai politik lainnya. PNI tidak berdaya memperjuangkan program-programnya ketika penguasa baru melaksanakan pembangunan dengan mengundang investor asing dan segelintir kalangan pengusaha lokal untuk mengeksploitasi sumberdaya alam yang meminggirkan rakyat dari basis kehidupannya.

Dalam dinamika politik yang berkembang, PNI menganggap fusi partai politik merupakan pilihan paling realistik, sehingga bersama empat partai politik lain melakukan fusi menjadi PDI.Sekjen I DPP PNI terakhir, Abdul Madjidyang menjadi salah satu deklarator PDI, mengatakan, "Sebelum DPP PNI memutuskan setuju atau tidak fusi, PNI di daerah-daerah sudah 'digarap' oleh pemerintah. Mereka sudah berfusi lebih dulu, memakai nama macam-macam. Kalau begini terus, akhirnya kita DPP kan menjadi tergusur. Sebagai Sekjen PNI saya membuat instruksi ke daerah supaya stop dulu fusi karena ini urusan pusat. Baru setelah itu diadakan rapat DPP PNI yang memutuskan setuju fusi.“" (Wawancara 13 Nopember 2006).

Di tengah desoekarnoisasi, isu fundamental menyangkut restrukturisasi penguasaan sumber ekonomi melalui reforma agraria tidak pernah diperjuangkan PDI karena dianggap sebagai bagian dari kebijakan Orde Lama. Pola represif Orde Baru membuat legitimasi kepemimpinan partai ditentukan oleh dukungan dari pemerintah. Kecuali terpilihnya Megawati tahun 1993, pemilihan Ketua Umum DPP PDI, pengurus lain lain, serta penyeleksian calon anggota legislatif diawasi secara ketat, antara lain melalui mekanisme penelitian khusus (litsus). Pola-pola seperti itu membuat PDI tidak mampu berperan menjalankan fungsi kontrol politik menghadapi kekuatan ekternal yang berada dalam kendali Soeharto. Di era kepemimpinan Soerjadi tahun 1986-1993, walaupun terdapat upaya kritis terhadap eksistensi Orde Baru, menyangkut isu konglomerasi dan demokratisasi politik, PDI tidak dapat melakukan perubahan politik karena keberadaannya sebagai partai kecil yang masih terkooptasi kekuasaan dan adanya masalah konsolidasi internal tidak mampu mendorong ke arah itu. Di era Megawati, PDI didorong oleh kalangan internal dan eksternal partai untuk melakukan perubahan politik, pemerintah lalu menyingkirkannya melalui penyelenggaraan "Kongres Medan” 1996.

Secara umum PDI menjadi bagian dari sentralisme politik dan ekonomi sehingga partai ini tidak mampu menjalankan keberpihakannya secara konkrit bagi rakyat kecil. Konflik pertanahan yang dihadapi para petani, masalah kesejahteraan dan kondisi kerja kaum buruh, serta penggusuran pedagang kecil, dan termarjinalnya sektor kelautan tradisional terus berlangsung selama masa Orde Baru. Adapun di era reformasi, PDI Perjuangan cukup berperan membangun struktur politik yang demokratis. Secara makro, perekonomian di masa pemerintahan Megawati juga baik, jika indikatornya adalah PDB dan pertumbuhan ekonomi.

PDI Perjuangan melalui kadernya yang menjadi Menteri Tenaga Kerja dan Transmigrasi, Jacob Nuwa Wea, berhasil memperjuangkan UU No 13 Tahun 2003 tentang Ketenagakerjaan yang meski terdapat keterbatasannyaseperti masalah tenaga kerja alihdaya (outsourching), tapi lebih menjamin kebebasan buruh untuk berorganisasi dan menetapkan upah berdasarkan kebutuhan hidup layak (KHL). PDI Perjuangan juga memperjuangkan nasib petani melalui pengontrolan harga pupuk dan pembatasan impor beras serta peningkatan taraf hidup nelayan melalui pembangunan stasiun bahan bakar bagi nelayan. Di era pemerintahan Megawati, Indonesia menolak ketergantungan dengan lembaga luar negeri seperti IMF. Namun, di tengah kehidupan politik yang kian pragmatis di era reformasi, PDI Perjuangan menghadapi kenyataan lunturnya nilai-nilai nasionalisme, praktik politik tanpa ideologi, dan berkembangnya liberalisasi ekonomi. Akhirnya, banyak kerjasama dan konflik PDI Perjuangan dengan kekuatan politik lain mengukuhkan pragmatisme politik ketimbang perjuangan berdasarkan platform ideologi. PDI Perjuangan lebih memperhatikan kepentingan perimbangan kekuatan antar elite ketimbang mengedepankan konsistensi perjuangan. Ketidakberanian PDI Perjuangan mendukung 
pembentukan Pansus Bulogate II yang melibatkan Ketua DPR Akbar Tandung, misalnya, menyebabkan kepanitiaan itu tidak berhasil dibentuk. Padahal sebelumnya, PDI Perjuangan menyetujui Pansus Bulogate yang melibatkan Presiden Abdurrahman Wahid.

PDI Perjuangan juga tidak mengelaborasi konsistensi orientasi ideologisnya untuk memberi kontribusi pada strategi negara dalam pengaturan ekonomi di masyarakat.Meski partai-partai nasionalis, termasuk PDI Perjuangan, memperoleh total suara mayoritas dalam Pemilu di era reformasi, namun di tengah semakin kuat kepentingan akumulasi modal yang menggerusperjuangan nasionalisme bagi rakyat kecil, bangsa ini semakin menjajakan kekayaan alamnya ke pihak asing, aset negara dijual, dan penduduknya tetap menjadi sumber tenaga murah. Proses demokratisasi politik banyak melahirkan para aktor yang lebih berorientasi kepentingan politik jangka pendek, untuk memperoleh sumber-sumber ekonomi di pusat dan daerah. Kebebasan politik yang diraih baru menghasilkan "ritualitas demokrasi" yang secara prosedural dan berkala memilih pemimpin-pemimpin politik pada Pemilu Legislatif, Pemilihan PresidenWakil Presiden, dan Pemilihan Kepala Daerah. Adapun bobot "spiritualitas" kedaulatan rakyat terus tersumbat jalinan relasi kepentingan modal dan politik dalam penguasaan sumber-sumber ekonomi.

\section{Aspek similarity-dissimilarity}

Dari aspek kesamaannya, baik PNI, PDI, maupun PDI Perjuangan berhasil menemukan identitas yang menunjukkan keberpihakannya kepada rakyat kecil. PNI menggunakan istilah "marhaen". Adapun di tengah desoekarnoisasi, PDI memakai istilah "partai sandal jepit", dan sejak akhir 1980-an mempopulerkan istilah "wong cilik" yang diadopsi dari bahasa Jawa, artinya rakyat kecil. Identitas pembelaan terhadap "wong cilik" itu digunakan pula oleh PDI Perjuangan. Ketiga partai itu cukup konsisten mendukung usaha mengatasi separatisme, konflik sosial, eksistensi Negara Kesatuan Republik Indonesia (NKRI), serta penegakan dasar negara Pancasila. Sebagai partai nasionalis, proses rekruitmen di tubuh PNI, PDI, dan PDI Perjuangan juga tidak memandang golongan atau strata manapun untuk menjadi anggota partai, baik kaya-miskin, priyayi-rakyat jelata, cendekiawan-orang yang tidak berpendidikan, dan apapun etnis/sukunya. Tapi tanpa mengelaborasi konsistensi orientasi ideologinya lebih jauh, ketiga partai menjadi sering lebih berorientasi memperjuangkan ideologi formal dan menyesuaikan diri dengan konstelasi kekuasaan yang berkembang. Adapun pembebasan rakyat kecil dari kondisi penutupan sosial dengan pengucilan belum diatasi.

PNI memiliki penekanan rumusan ideologi yang berubah-ubah. Konflik di tubuh PNI merupakan konflik antar elite dalam menyikapi persoalan penekanan garis ideologi, distribusi sumber-sumber kekuasaan, dan relasinya dengan kekuasaan pemerintahan. Pada masa Demokrasi Terpimpin, wacana "marhaenisme sebagai marxisme yang diterapkan di Indonesia" berkembang. Istilah itu pertama kali dinyatakan oleh Soekarno ketika menerima delegasi Konferensi Pendidik Marhaenis di Bogor sekitar bulan Mei 1958 (Maliki 1968:62). Istilah "marhaenisme sebagai marxisme yang diterapkan di Indonesia" itu lalu menjadi perdebatan keras di internal PNI pada tataran ideologis dan politis-praktis yang menjadi identitas garis kubu kiri dan kanan di partai ini. Di era awal Orde Baru, penekanan ideologinya bergeser dengan mengidentifikasikan marhaenisme dengan Pancasila. Perubahan penekanan tersebut berkaitan dengan pergeseran pusat kekuasaan dan dinamika politik yang berkembang. PNI memiliki sejumlah jaringan organisasi horizontal (pemuda, mahasiswa, dan wanita) dan vertikal (birokrasi, buruh, tani, dan nelayan) yang banyak dibangun setelah Pemilu 1955. Meski begitu, tidak semua jaringannya berjalan efektif, bahkan partai ini agak terlambat dan kalah agresif ketimbang PKI membangun jaringan kemasyarakatan bagi rakyat kecil, seperti buruh dan kaum tani.

Pada Pemilu 1955, meski PNI memperoleh kemenangan di daerah pedesaan di Jawa, tapi di lima karesidenan di Pulau Jawa yang terdapat kemiskinan ekstrem, yakni: Semarang, Yogyakarta, Surakarta, Madiun, dan Kediri, PKI justru menjadi partai terkuat dan PNI hanya menempati posisi kedua (Feith 1957:84-5). Hal itu menjadi indikator kegagalan PNI bersaing dengan PKI untuk 
memberi kepemimpinan politik bagi petani miskin dan buruh tani sehingga mereka lebih tertarik dengan perjuangan PKI. Kemenangan PNI yang lebih berbasis di pedesaan juga menunjukkan bahwa partai ini kurang berhasil menggarap pedagang kecil di kota-kota besar dan masyarakat daerah-daerah luar Jawa. Di Jawa sendiri PNI lebih banyak memperoleh dukungan di Jawa Tengah dan Jawa Timur. Di sisi lain, Masyumi banyak memenangkan suara di daerah perkotaan di Jawa dan memiliki sebaran suara Jawa-luar Jawa yang lebih baik dari PNI (Feith 1957:57-91).

Adapun PDI adalah partai kecil hasil fusi lima partai yang terkooptasi kekuasaan Orde Baru. Keberadaannya dalam konteks restrukturisasi politik dan deideologisasi Orde Baru. Jika penekanan PNI terhadap ideologi berubah-ubah, hampir sepanjang Orde Baru PDI dapat dikatakan "konsisten" dalam penekanan ideologinya, yakni mendukung tafsir Pancasila dari penguasa. Dukungan terhadap dwifungsi ABRI, kebijakan pembangunan Orde Baru, dan kepemimpinan nasional oleh Presiden Soeharto dijadikan sikap politik politik PDI tidak memiliki jaringan yang luas. Pola massa mengambang hanya memperbolehkan partai politik memiliki struktur kepengurusan hingga tingkat kabupaten/ kota, adapun kepengurusan di tingkat kecamatan dan desa hanya berbentuk komisariat yang tidak melibatkan partisipasi masyarakat. PDI tidak mampu mengisi seluruh jaringan struktural yang ada karena selain rakyat kurang melihat manfaat partai ini bagi mereka, pola represif Orde Baru membuat adanya ketakutan di masyarakat untuk aktif di organisasi politik di luar Golkar. Adapun jaringan birokrasi yang sebelumnya menjadi andalan PNI sudah dipangkas melalui monoloyalitas terhadap Golkar. PDI juga tidak mampu membangun jaringan profesi karena dipisahkannya kalangan profesional dari partai politik dan keterbatasan sumber daya manusia. Selain itu, PDI tidak memiliki organisasi kemasyarakatan, baik pemuda, mahasiswa, wanita, buruh, tani, maupun nelayan, sebagai sumber proses rekruitmen dan pengkaderan. Sumber kader PDI lebih mengandalkan ormas-ormas dari kelima partai yang berfusi, seperti Pemuda Demokrat, GMNI dan GMKI, yang tidak ada hubungan struktural dengan partai ini.

Hampir sepanjang masa Orde Baru, partai ini tidak memperoleh dukungan dari kalangan pengusaha besar. Para pemodal khawatir usahanya terganggu jika mendukungnya. Keterbatasan itu membuat PDI memiliki hubungan ketergantungan pendanaan dengan pemerintah. Kerjasama PDI dengan kekuatan politik lain adalah dalam rangka mendukung kebijakan pembangunan Orde Baru. Ketika PDI dipimpin Megawati, partai ini mulai membangun kerjasama dengan kekuatan politik lain untuk tujuan demokratisasi dan transisi kepemimpinan nasional, sehingga berkonflik dengan negara dan pemerintah.

Konflik-konflik di tubuh PDI lebih cenderung merupakan konflik antar elit partai untuk memperebutkan sumber-sumber kekuasaan di partai dan jabatan pemerintahan (khususnya di lembaga legislatif) dalam ruang politik yang terbatas. Kecuali konflik PDI Megawati versus PDI Soerjadi, konflik-konflik yang terjadi sepanjang sejarah PDI tidak menyangkut usaha untuk menegakkan kemandirian partai dan tak menghasilkan dukungan rakyat terhadap salah satu pihak yang berkonflik. Secara umum, konflik di tubuh PDI Perjuanganlebih merupakan konflik antar elite menyangkut pola pengorganisasian dan kepemimpinan di dalam partai. Hanya Partai Demokrasi Perjuangan Rakyat (PDPR) yang didirikan pada 2002 oleh segelintir mantan aktivis PDI Perjuangan di tingkat akar rumput tidak melibatkan satu pun tokoh sehingga partai ini tidak menarik minat para aktivis PDI Perjuangan lainnya (Setiawan dan Nainggolan [ed] 2004:461). Sebagai produk represi Orde Baru, PDI Perjuangan yang merupakan kelanjutan dari PDI menyisakan kerapuhan ideologi, struktural, dan personal.Wakil Sekretaris Jenderal DPP PDI Perjuangan 2000-2005, Jacobus K. Mayongpadang mengakui DPP PDI Perjuangan periode ini tidak memiliki rencana kerja yang berkesinambungan melainkan hanya menjalankan kegiatan yang bersifat insidentil. Kegiatan yang lebih diperhatikan adalah menyangkut persoalan menyiapkan calon dalam Pemilihan Kepala Daerah. Akibatnya, DPP PDI Perjuangan periode tersebut belum mencapai pemantapan pengorganisasian dan ideologi. Dalam persoalan kaderisasi, menurut Jacobus, selain jumlah yang dikader masih kecil, banyak orang mengikuti pengkaderan lebih berorientasi pada keinginan mencari skor dalam rangka pencalegan di DPR RI/DPRD dan bukannya untuk penanaman nilai perjuangan (Wawancara 12 September 2006). Di satu sisi, PDI 
Perjuangan berhasil membangun jaringan secara struktural, yakni dari kepengurusan pusat hingga tingkat kelurahan/ desa,namun hingga kongres tahun 2005 PDI Perjuangan tidak membangun jaringan vertikal masyarakat (buruh, tani, dan nelayan) dan jaringan horizontal masyarakat (pemuda, mahasiswa, dan wanita). Padahal sebagai partai pemenang Pemilu 1999 PDI Perjuangan memiliki basis massa luas dan pendanaan tidak sedikit. Ketidakseriusan PDI Perjuangan membangun jaringan partai di masyarakat berdampak pada kapasitas organisasi untuk lebih mendekatkan partai dengan rakyat serta pola rekruitmen untuk melahirkan para pemimpin partai yang lebih berkualitas dan berpengalaman mengorganisir rakyat. Akhirnya, massa yang mendukungnya bersifat cair sehingga PDI Perjuangan dengan mudah kehilangan sekitar $15 \%$ suara pada Pemilu 2004 dibandingkan Pemilu 1999.

\section{Aspek kontinuitas-diskontinuitas}

Pada 23 Agustus 1945 Soekarno mengeluarkan dekrit PNI sebagai partai negara (staatpartij) dengan tugas menggerakkan rakyat bersatu mendukung perjuangan kemerdekaan. Meski PNI Staatpartij tidak berjalan, di sejumlah tempat berdiri sejumlah partai nasionalis. Pada Kongres Serikat Rakjat Indonesia yang pertama di Kediri tanggal 28 Januari-1 Februari 1946, partai-partai itu, yakni Serikat Rakjat Indonesia, PNI Sulawesi, PNI Sumatera, PNI Madiun, Partai Republik Indonesia (Madiun), dan Partai Kedaulatan Rakjat (Yogyakarta) memfusikan diri menjadi Partai Nasional Indonesia (PNI) dengan asas marhaenisme (Panitia Penerbitan Buku Empat Windu PNI 1959:118).

Organisasi ini memilih nama PNI untuk mengindentikkan diri dengan PNI yang didirikan Soekarno tahun 1927. Padahal, PNI 1927 belum memiliki asas marhaenisme. Asas marhaenisme baru dinyatakan secara tertulis oleh Soekarno di Pengadilan Kolonial di Bandung tahun 1930. Nama PNI dan Soekarno beserta ajarannya pada masa itu sudah dikenal di kalangan pendukung kemerdekaan, sehingga penggunaan nama PNI dan simbol-simbol Soekarno mempermudah organisasi ini meraih dukungan secara luas. Semangat PNI tahun 1927 dan 1946 juga sama, yakni anti kolonialisme, kapitalisme, dan imperialisme. Isu nasionalisasi tahun 1957 yang didukung PNI adalah cita-cita PNI tahun 1927 agar bangsa Indonesia mengurus diri sendiri (self-help). Pola aksi massa PNI era kemerdekaan juga melanjutkan cara-cara PNI era kolonial. Meski begitu, PNI di era kemerdekaan berbeda dengan PNI tahun 1927 dalam hal orientasi kekuasaan. PNI tahun 1927 lahir dari bawah, yakni para tokoh pergerakan yang mampu menyerap aspirasi rakyat. Tujuan PNI tahun 1927 adalah kemerdekaan, sehingga partai ini menjadikan kolonialisme Belanda sebagai musuh bersama.

Adapun PNI era kemerdekaan lahir dari atas, didirikan para elite dari negeri yang baru merdeka, yang bercampur kepentingan meraih sumber-sumber kekuasaan dan ekonomi, sehingga berdampak pada konsolidasi internal dan distribusi kekuasaan. Kepentingan kalangan borjuasi dan feodal lambat laun mempengaruhi praktik politik partai ini. Akhirnya, PNI di era kemerdekaan tidak hanya memiliki musuh nekolim (neo kolonialisme dan imperialisme), melainkan juga di dalam negeri dan internal partai sendiri terdapat hambatan memperjuangkan restrukturisasi penguasaan sumber-sumber ekonomi bagi kepentingan rakyat kecil. Ketika Orde Baru melakukan deideologisasi, desoekanoisasi, dan depolitisasi, PNI mengalami "pengordebaruan". Bersama 4 partai lain PNI memfusikan diri ke dalam PDI. Kalangan PNI berusahamentransformasikan asas sosio-nasionalisme dan sosio-demokrasi dari marhaenisme ke dalam bahasa lain. PDI disebutkan memiliki asas Pancasila dengan watak dan ciri demokrasi Indonesia, kebangsaan Indonesia, dan keadilan sosial. Sekjen I PNI terakhir Abdul Madjid menjelaskan, menjelang fusi PDI 1973 berlangsung Sidang MPP PNI yang bukan hanya menyetujui fusi tapi juga terdapat amanat tak tertulis bahwa "PNI harus mem-PNI-kan PDI, PDI harus bersemangat PNI". Intinya, semangat marhaenisme harus masuk di PDI (Wawancara 15 Nopember 2006).

Tapi PDI tidak pernah menyatakan dirinya memiliki watak progresif-revolusioner sebagaimana halnya PNI. PDI lahir dari atas, sebagai hasil proses fusi yang dipaksakan oleh penguasa militer. Dalam proses tersebut, Orde Baru menyingkirkan kalangan PNI dan empat partai lain yang tidak 
mendukung orientasi politiknya. Pola stabilitas politik dan pembangunan Orde Baru membuat mereka yang ingin aktif di PDI harus menanggalkan keinginannya melakukan restrukturisasi penguasaan sumber-sumber ekonomi di masyarakat. Sebagai partai kecil yang tidak memiliki jaringan kuat di masyarakat, PDI dijadikan alat oleh penguasa Orde Baru untuk melegitimasi kebijakan pembangunannya yang terus memperlebar ketimpangan penguasaan sumber-sumber ekonomi.

Adapun PDI Perjuangan lahir melalui proses dari bawah sebagai perlawanan terhadap sentralisme kekuasaan dan politik represif Orde Baru. Melalui perjalanan selama 6 tahun sejak Megawati terpilih melalui Kongres Luar Biasa (KLB) PDI 1993, aspirasi arus bawah pendukung Megawati tidak dapat dibendung meski pemerintah tidak mengakui keberadaannya secara legal pada 1996. Kristalisasi di tubuh PDI itu melahirkan PDI Perjuangan pada era reformasi. Tapi PDI Perjuangan tidak memiliki watak progresif-revolusioner. Desakan liberalisasi ekonomi yang semakin kuat dan kehidupan politik yang kian pragmatis membuat PDI Perjuangan kurang mengembangkan orientasi ideologis yang secara fundamental memberdayakan rakyat kecil. Di tengah kerapuhan ideologis pasca depolitisasi Orde Baru, langkah politik PDI Perjuangan tidak sampai melakukan restrukturisasi penguasaan sumber-sumber ekonomi secara mendasar.

Undang-Undang Pokok Agraria (UUPA) tahun 1960 belum dicabut, tapi penguasaan tanah di masyarakat semakin timpang.Dalam laporan pertanggung jawaban DPP PDI Perjuangan Periode 2000-2005 setebal hampir 300 halaman pada Kongres II tahun 2005 PDI Perjuangan hanya menyebut urusan pertanahan dalam satu paragraf di bagian lampiran dengan materi yang cenderung bersifat normatif. Demikian halnya dalam restrukturisasi penguasaan modal, aliran kredit tetap jauh lebih banyak dan mudah diakses pengusaha besar ketimbang usaha mikro, kecil, menengah, dan koperasi. Selain itu, meski negara mengakui keanekaragaman budaya, namun dalam konteks penguasaan sumber-sumber ekonomi dan politik, hak-hak adat dan sektor tradisional masih dimarjinalkan. Ketimpangan penguasaan sumber-sumber ekonomi Indonesia menempatkan Indonesia terus menjadipenjaja tenaga kerja murah dan lemah posisi tawarnya. Ancaman pemecatan terus menjadi masalah besar bagi kaum buruh. Pakpahan (2010:215) menyatakan: "As long as there are worker dismissals, it would be near impossible to build healthy industrial relations, of which, according to the law are democratic, dynamic, harmonious, fair, and prosperous".

Akhirnya, dapat dikatakan, baik PNI, PDI, maupun PDI Perjuangan sama-sama memiliki ideologi yang mengaitkan nasionalisme dengan kepentingan rakyat kecil. Namun, ketiganya mengalami diskontinuitas satu sama lain, dari berwatak progresif-revolusioner, kemudian terpaksa menjadi pendukung "ideologi pembangunan" Orde Baru, hingga menjadi partai yang cenderung mencair dalam perjuangan ideologinya. Di tengah perbedaan watak tersebut, ketiga partai ini sama-sama mengalami diskontinuitas antara ideologi dan praktiknya, yakni tidak solid memperjuangkan nasionalisme bagi rakyat kecil ketika menghadapi kepentingan akumulasi modal sehingga tidak terjadi restrukturisasi penguasaan sumber-sumber ekonomi untuk memperbaiki ketimpangan sosial secara mendasar di masyarakat.

\section{Simpulan}

Sejak masa kolonial, di negeri ini beroperasi ideologi yang mengeksploitasi sumber daya alam dengan memisahkan rakyat dari basis kehidupannya. Ideologi eksploitatif itu memaksimalkan ganjaran melalui pemonopolian kesempatan, khususnya kesempatan ekonomi, kepada segelintir pihak atau disebut Frank Parkin sebagai penutupan sosial dengan pengucilan, sehingga menumbuhkan kelas kepemilikan negatifatau rakyat kecil. Untuk menghadapi ideologi eksploitatif, nasionalisme dikaitkan gagasan keadilan sosial untuk membebaskan rakyat kecil. Dalam politik nasional, fenomena rakyat kecil dan kemiskinannya melahirkan istilah khasnya sebagai pembelaan terhadap mereka, yakni marhaen dan wong cilik. Rakyat kecil sendiri sudah banyak mengorganisir diri (self-help) melalui pengembangan usaha mikro, kecil, dan kolektif (koperasi). Namun, posisi rakyat kecil tetap rentan secara struktural. 
Memang dirasakan sangat penting adanya instrumen sosial berupa pemerataan akses pendidikan dan kesehatan yang berkualitas, hingga pelaksanaan sistem jaminan sosial yang tepat sasaran. Tetapi lebih dari sekadar prinsip welfare state, ketimpangan penguasaan aset produksi seharusnya dikoreksi yang berbeda dengan perjuangan kelas ala komunisme yang bertujuan meniadakan hak milik, melainkan pembebasan dari sistem yang menindasnya. Dalam konteks Indonesia, jika hak milik atas aset produksi dihapus maka itu akan merugikan berbagai profesi rakyat kecil yang memiliki aset produksi. Nasionalisme bagi rakyat kecil bukan bertujuan menghapus hak milik, melainkan justru distribusi penguasaan aset produksi yang lebih adil dan merata. Cara perjuangan pembebasan rakyat kecil terletak pada level perubahan struktural yang memberi kesempatan luas bagi rakyat kecil untuk melakukan mobilitas vertikal. Kaum tani, nelayan, serta pedagang dan industri kecil dapat memperbarui aset produksi dengan penyediaan akses kredit seluasnya kepada mereka, ditunjang pembenahan infrastruktur, manajemen, dan jaringan perdagangan. Adapun industrialisasi yang dikembangkan berorientasi penguasaan teknologi tinggi dengan mensyaratkan pemodal untuk melakukan alih teknologi.

Transformasi bagi keadilan sosial memerlukan reforma agraria untuk merombak ketimpangan struktur penguasaan tanah yang menyebabkan perbedaan kuasa dan kemampuan menjangkau akses terhadap modal dan sarana produksi. Selama ini, segelintir pemodal besar melakukan penguasaan tanah melalui mekanisme hak guna usaha dan hak penguasaan hutan. Selain mengoreksi ketimpangan hak milik di mana kelebihan tanah diganti rugi negara untuk dibagikan kepada petani gurem dan buruh tani, negara perlu memprioritaskan pemberian hak pakai kepada koperasi desa yang mengatur pengelolaan dan bagi hasil untuk petani. Penguasaan basis material perdagangan oleh kaum tani mendorong kedaulatan pangan nasional berbasis pemberdayaan masyarakat lokal. Pemerintahan yang bersih dan efisien mendorong keberpihakan pada kedaulatan bangsa dan kehidupan rakyat di dalamnya. Peninjauan kembali kontrak sektor pertambangan yang banyak merugikan negara dan memarjinalkan masyarakat setempat juga perlu dilakukan, agar dapat diperuntukkan sebesar-besarnya bagi kemakmuran rakyat. Secara sosiologis hal ini berarti nasionalisme harus mempertimbangkan kekuatan ekonomi, politik, dan sosial budaya di dalam masyarakat. Nasionalisme tidak dapat menjadi bagian dalam diri rakyat kecil jika sejarah nasionalisme hanya merupakan sejarah negara dan kelompok-kelompok dominan. Hal itu menjadi landasan bagi tujuan mencapai masyarakat tanpa pemiskinan, pembodohan, dan penindasan di tingkat nasional dan global. Jika dibandingkan dua ideologi besar dunia, komunisme dan kapitalisme, politik-ekonomi dari nasionalisme bagi rakyat kecil dapat dijelaskan dalam bagan 1 . 


\section{Bagan 1.}

Perbandingan politik-ekonomi dari nasionalisme bagi rakyat kecil dengan komunisme dan kapitalisme

Komunisme

\section{Tujuan:}

- Kekuasaan di tangan kelas proletar karena penguasaan alat produksi oleh negara memperkuat posisi tawar kaum proletar, untuk kemudian tidak ada lagi negara (negara bersifat ad hoc).

- Mencapai masyarakat tanpa kelas. Individu memperoleh sesuai kebutuhannya, meski tingkat kerja kerasnya berbeda.
Nasionalisme bagi rakyat kecil

Tujuan:
- Kekuasaan berada di tangan segenap
lapisan masyarakat karena adanya
persamaan hak-hak dasar di bidang
politik, ekonomi, dan sosial-budaya, di
mana eksistensi negara selalu
diperlukan untuk membela kepentingan
rakyat kecil.
Mencapai masyarakat tanpa pemiskinan,
pembodohan, dan penindasan dalam
konteks nasional dan internasional. Apa
yang diperoleh setiap individu berbeda
semata-mata tergantung tingkat kerja
keras masing-masing.

Kondisi Awal:

Menghendaki adanya kesempatan yang sama bagi setiap orang melalui penguasaan alat produksi oleh negara, hak milik pribadi atas aset produksi tidak diakui.

-Perjuangan kelas sosial antara kelas proletar melawan kelas kapitalis dalam kerangka internasionalisme.

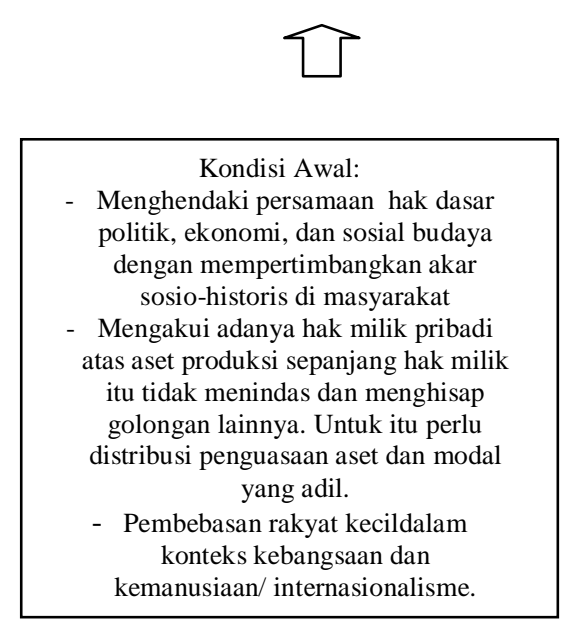

Kondisi Awal:
Kapitalisme

Keadaan yang terjadi:

- Meski dijamin persamaan hak-hak dasar di bidang politik, tetapi karena tidak adanya persamaan hak-hak dasar di bidang ekonomi dan sosial-budaya, maka

kekuasaan didominasi kepentingan kelas sosial-ekonomi atas.

- Kemiskinan dan penindasan struktural.

Apa yang diperoleh setiap individu

berbeda karena disamping berbeda dalam tingkat kerja kerasnya juga terdapat ketimpangan kesempatan.

Namun, meski nasionalisme dikaitkan dengan keadilan sosial, praktik nasionalisme di Indonesia, sebagaimana direpresentasikan oleh PNI, PDI, dan PDI Perjuangan, belum membebaskan rakyat kecil dari penutupan sosial dengan pengucilan dalam medan konflik dan ompromi antar kekuatan politik lain, kekuatan modal, maupun relasi dengan negara dan pemerintah di tengah kondisi pascakolonial. Orientasi politik partai nasionalis tidak sampai tahap pengoreksian secara fundamental ketimpangan basis material dan dominasi ideologi kelas dominan. Padahal, kegagalan mengelaborasi persoalan keadilan sosial ke arah kerjakerja konkrit tidak hanya melemahkan konsolidasi demokratisasi politik. Lebih jauh lagi, bangsa ini mengalami kesulitan membangun politik-ekonomi yang berdaya saing untuk melakukan transformasi sosial.

\section{Daftar Pustaka}

Adams C (1966) Bung Karno penjambung lidah rakjat Indonesia. Djakarta: Gunung Agung.

Badan Pusat Statistik (2005a) Sensus pertanian 2003: Angka nasional hasil pendaftar rumah tangga. Jakarta: BPS.

Badan Pusat Statistik (2005b) Sensus pertanian 2003: Hasil pencacahan survei pendapatan rumah tangga pertanian. Jakarta: BPS.

Bagin (2002) Partai Nasional Indonesia: Sekilas analisa kritik diri. Jakarta: Yayasan Seni Budaya "Gema Patriot" dan Promedia. 
DPP PDI Perjuangan (2005) Laporan pertanggungjawaban dewan pimpinan pusat PDI Perjuangan masa bhakti 2000-2005 dalam Kongres II PDI Perjuangan di Bali, 28 Maret-2 April 2005. Jakarta: DPP PDI Perjuangan.

Feith H (1957)The Indonesian elections of 1955. Ithaca, New York: Modern Indonesia Project, Cornell University, Interim Report Series.

Geertz C(1986)Mojokuto: dinamika sosial sebuah kota di Jawa. Jakarta: Grafiti Pers.

Gramsci A (1995) Selections from the prison notebooks. London: Lawrence \& Wishart.

Jalal(2003) "Teori Kelas" dalam perdebatan kontemporer. Jurnal Sosiologi, Masyarakat12:135147.

Kaligis RAW (2010) Keluar dari jeratan "Bangsa Kuli”. Kompas, 6 Desember, h. 6.

Khudori (2007) Petani, kemiskinan, dan reforma agraria. Kompas, 16 Maret, h.6.

Kusnadi (2003) Akar kemiskinan nelayan. Yogyakarta: LKIS.

Loomba A (2005) Colonialism/postcolonialism. New York: Routledge.

Mintz JS (2002) Muhammad, Marx, Marhaen: Akar sosialisme Indonesia, Yogyakarta: Pustaka Pelajar.

Maliki O (1968) Marhaenisme berlawanan dengan marxisme, ceramah dalam kursus kader wanita Marhaenis DCI Djaja (stensilan).

Neuman WL (2003) Social research methods: qualitative and quantitative Approaches $5^{\text {th }}$ edition, Boston: Allyn and Bacon.

Panitia Penerbitan Buku Empat Windu PNI(1959) Empat windu Partai Nasional Indonesia 4 Djuli 1927-4 Djuli 1959. Semarang: DPD PNI Jawa Tengah.

Pakpahan M (2010) Welfare State, The 1945 Constitution, and Industrial Relations. Journal of Administrative Sciences \& Organization, Bisnis \& Birokrasi 17 (3):209-217.

Parkin F (1979) Marxism and class theory: A bourgeois critique. London: Tavistock Publications Limited.

Paul JD (1986) Teori sosiologi: klasik dan modern (Jilid 1), diterjemahkan oleh Robert M.Z. Lawang. Jakarta: Gramedia.

Republik Indonesia. Undang-Undang No. 13 tahun 2003 tentang Ketenagakerjaan, Lembaran Negara Tahun 2003 No. 39.

Rocamora JE (1991) Nasionalisme mencari ideologi: bangkit dan runtuhnya PNI 1946-1965. Jakarta: PT Pustaka Utama Grafiti.

Setiawan B \&Nainggolan B (ed) (2004) Partai-partai politik Indonesia: Ideologi dan Program 2004-2009. Jakarta: Penerbit Buku Kompas.

Soenario (1988) Banteng segitiga. Jakarta: Yayasan Marinda.

Somantri GR(2005) Memahami metode kualitatif. Jurnal Makara, Sosial Humaniora Vol. 9(2):5765.

Soekarno (1984) Pancasila sebagai dasar negara. Jakarta: Inti Indayu Press.

Supriana T\& Nasution VT(2010) Peran usaha TKI purna terhadap pengembangan ekonomi lokal dan faktor yang mempengaruhi pendapatan usaha TKI purna di Provinsi Sumatera Utara. Jurnal Makara: Sosial Humaniora 14 (1):42-50.

Tjondronegoro SMP \& Wiradi G (ed) (2008) Dua abad penguasaan tanah: pola penguasaan tanah pertanian di Jawa dari masa ke Masa. Jakarta: Yayasan Obor Indonesia.

Widarjono A (2002) Sony dan problematika "footlose industry". Kompas, 11 Desember, hal. 6.

Madjid A (2006)Wawancara 13 Nopember.

Mayongpadang JK (2006)12 September. 